UDC 811.111'373.7'42

DOI https://doi.org/10.32841/2409-1154.2021.48-3.33

\author{
Shumenko O.A., \\ Candidate of Philological Sciences, \\ Associate Professor at the German Department \\ Sumy State University \\ Kashenko P. V., \\ Master's Student at the German Department \\ Sumy State University \\ Savchenko Ye. O., \\ Master's Student at the German Department \\ Sumy State University
}

\title{
ENGLISH LEGAL TERMINOLOGY IN THE CONTEXT OF ARTISTIC TRANSLATION
}

Summary. The article is devoted to English legal terminology in the context of literary translation. The choice of this topic is due to the fact that the main problems in the translation of works of art and films in which there is a legal discourse, may be associated not so much with limited knowledge of the translator in legal terminology, but with the preservation of the author and stylistic functions of the term. Thanks to the concepts developed in this article, the peculiarities of the ways of translation and reproduction of the problems that arose during the translation of legal terminology were revealed. The article focuses on the terminology used in the legal field and on examples of their use in fiction and film. Before proceeding to the formation of the main results of this work, it was necessary to correctly delineate the concept of "legal term", so a definition was formed, which stated that the legal term is a linguistic definition of state and legal concepts, which expresses and the content of normative legal orders of the state is fixed.

This paper considers the peculiarities of the translation of legal terminology, as the main role in the translation of legal texts is played not only by knowledge of legal norms, legal terminology, judicial systems, but also the personal qualities of the translator, as the translation of any text allows interaction of two sovereign national languages, as well as intercultural aspects.

First of all, the specifics of educational technical and artistic translation are considered, which provides special literature in the field of law. The analysis of sources and types of legal terms of English is carried out. The main translation difficulties that may arise when working with English-language literary text, which includes legal terminology, are outlined. The lexical and grammatical transformations used during the translation of a legal text are analyzed.

Key words: legal terminology, legal discourse, artistic discourse, legal system, translation methods.

Modern linguistics increasingly perceives the term as a unit that functions and develops in the text. This approach involves a dynamic interpretation of the term and its viewing primarily as a textual phenomenon. Because of this, the term should be considered not only as a unit of nomination of special concepts, but also as a linguistic component of functional style.
The urgency of the topic is due to the fact that Englishlanguage legal television series and literature covering legal issues shed light on the legal aspect of modern life, which helps to develop the legal self-knowledge of the recipient. Since works of art that involve some professional specificity can often present significant difficulties for translation.

Formulation of the problem. Although the main problems in translating English legal terminology in a detective work of art or film may be related not so much to the limited knowledge of the translator in jurisprudence, but to the preservation of the author's intention and stylistic functions of the term, so translation in this type of information transmission of this information. There is a huge amount of scientific work in the field of translation of legal terms in special texts, the topic of functioning and translation of this terminology in literary texts is little studied.

The aim of the article is to study and analyze English terminology on the material of artistic legal discourse and identify ways of translation. And also to study the features and methods of transferring English-language realities into the language of translation on the example of legal terms found in special texts, and specifically in fiction and cinematography.

The theoretical significance of this work is that the general issues of translation of legal terminology in non-special texts are little studied, although it needs to be highly studied.

The practical significance of the work lies in the application of research results in the practical activities of translators in the field of translation of fiction and film text, as well as lectures and practical classes on the theory and practice of translation in higher education.

Traditionally, the term is represented in the linguistic literature by the following qualities: definiteness, unambiguity, nominativeness, systematicity, stylistic and emotionally expressive neutrality. The specifics of the legal term is heterogeneous and it is possible to distinguish the terminology of law and the terminology of jurisprudence. This division, in turn, is associated with different areas of functioning of legal terminology, namely official business and scientific [1, p. 146].

Legal terminology is characterized by such qualities as unambiguity, consistency of use, expressive neutrality, which help to draw analogies with legal terms, as well as to fix specific 
definitions and ideas on the objects of discourse, avoiding undesirable interpretations and the specified area, content and nature of law [2, p. 14-16]. Among the main distinguishing features of legal terminology are monosemanticity, severity and clarity of meaning, the presence of an unambiguous interpretation of the definition in dictionaries and comprehensive explanations in specialized directories. All these features must be taken into account, as they are the basis for the formation of a stylistic effect, which creates a strict unambiguous terminology in the creative approach to the artistic legal text [3, p. 35].

The legal text provides a specialized variety of professional communication and adheres to strict coordination in terms, therefore for each of them there is a strictly fixed norm of nomination. Another specific feature of the legal text is the lack of expressiveness. The legal text does not allow the use of language units with emotional and evaluative connotations, colloquial, vernacular, dialect words and phraseological inflections [4, p. 111].

However, the greatest interest in the context of literary translation is still those cases when terms for some reason can be translated by the full equivalent: the lack of equivalent in the language of translation, the difference between the two languages in sentence construction, the mismatch of connotative meanings with subsequent loss of stylistic effect term when translating its full equivalent [5, p. 314-315]. For example, the same English term inquest depending on the context was translated into two researched works with the help of several different terms of the Ukrainian language: ukr. слідство, судове слідство, попереднс слухання, дізнання, попереднє розслідування, which is evidence of inconsistency in the scope of meanings of terms in two or more languages and, if necessary, the application of such a lexical transformation as differentiation, for example:

- eng. Whatever we may think or suspect, it is better to say as little as possible for the present. The inquest isn't until Friday. (Agatha Christie, "The Mysterious Affair at Styles"). - ukr. Що б ми не думали, не підозрювали, в цей час краще говорити якомога меньше, доки не завершиться попередне слухання. Воно відбудеться в п'ятнищю;

- eng. In the interval before the inquest, Poirot was unfailing in his activity. Twice he was closeted with Mr. Wells. He also took long walks into the country. (Agatha Christie, "The Mysterious Affair at Styles"). - ukr. Аж до того дня, на який було призначено дізнання, Пуаро невпинно діяв: двічі він про щось радився з містером Уелсом за закритими дверима $і$ постійно довго прогулювався округом.

In the case when the full equivalent of the term in the language of translation in combination with the context does not convey the meaning laid down by the author, the use of modulation, ie semantic development is justified [6, p. 61]. For example, the English termeng. false pretensesin the Ukrainian language is equivalent to the term обман. Although in the following example, the context of the work requires the use of the term шантаж, as it more accurately conveys the nature of the actions of the offender. Example: eng. Don't see what else we can do. We can't very well hold him for obtaining money on false pretenses. Can't prove a ruddy thing. (Agatha Christie, "The murder of Roger Ackroyd"). - ukr. Що ж нам залишається робити? Мине можемо затримати його за звинуваченням в шантажі. Жодного доказу!

In other cases, inconsistencies in the ways of constructing a sentence force the use of grammatical transformations, namely, the choice of another part of speech, for example: eng. Tell me, Hastings, you yourself - have you no suspicions of anybody? (Agatha
Christie, "The Mysterious Affair at Styles"). - ukr. Скажimb, Гастінгс, ви самі... ви кого-небудь підозрюєте?

It is also possible to use the replacement of part of the language in translation in order to facilitate the understanding of the text to the reader. In the following example, the meaning of the term blackmailing is supported by the negative connotation of the lexical unit scoundrel, for example: eng. And she steadfastly refused to give me the name of the scoundrel who had been blackmailing her. (Agatha Christie, "The murder of Roger Ackroyd"). - ukr. I навidpiз відмовилась називати мені ім'я шантажиста.

However, in this case the term шантаж is used instead of scoundrel, as this terminological unit in the Ukrainian language already has the terminological meaning of the subordinate clause, for example: eng. "Who had been blackmailing her" and the negative connotation of the word scoundrel, which helped to significantly shorten the sentence and facilitate its perception by the reader.

In some cases, it is important to omit the term when translating, which leads to a partial loss of meaning of the text. For example, the term inquest is one of the key language units, although in translation it is not reflected: eng. "There would be pictures of Styles, snap-shots of "The family leaving the Inquest" - the village photographer had not been idle!" (Agatha Christie, "The Mysterious Affair at Styles"). ukr. Будуть опубліковані фотографії Стайлз-Корт, знімки членів родини... Місиевий фотограф часу марно не втрачав!

The omission of the term in this case deprived the reader of the idea of the emotional state of family members, which is laid down in eng. leaving the Inquest.

Particularly negatively affects the text of the translation of the omission of the term used in the stylistic technique [7, p. 164]. Thus, in the following example, the omission of the term led to a complete loss of expressiveness, which was based on the terminological meaning of the lexical units matrimonial and arrested and was used for additional characteristics of the characters as specialists using special vocabulary:

- eng. In the years that followed, Ackroyd showed no disposition to make a second matrimonial adventure (Agatha Christie, "The murder of Roger Ackroyd"). - ukr. Другий раз Екройд не одружсився;

- eng. Mon ami, have you ever, when writing a letter, been arrested by the fact that you did not know how to spell a certain word? (Agatha Christie, "The Mysterious Affair at Styles"). - ukr. Друг мій, чи траплялось вам іноді забувати, як правильно пишеться яке-небудь слово?

It should be noted that the main ways of translating legal terms in the works of Agatha Christie were to use their full equivalents, as in most cases, they have the same connotative meaning, which helps to preserve their stylistic functions and expressiveness of translation. In cases where equivalents in the language of translation are absent, or differ in connotative meaning, the degree of expressiveness, which leads to the impossibility of transmitting the desired stylistic effect, often come to the aid of such lexical transformations as modulation and differentiation. And the inconsistency of ways of constructing a sentence in two languages entails the need for grammatical transformations, as well as the replacement of part of the language in translation. The omissionof the term whentranslating a literary textdoes not contribute to the simplification of perception and understanding, as the translated text is deprived of expressiveness and stylistic effect, which are based on the terminological meaning of the lexical unit of language for special purposes [8, p. 96-97]. 
Translation of lexical units with a change in terminology can be divided into two groups, namely:

- terms of the original text that completely or partially lose their terminological character in the translated text

- common vocabulary of the original text, which has a semantic development in the translation process and is transformed into a term [9, p. 147-149].

Consider the lexical units of the first group in the film context. To conduct this analysis, several episodes of the English-language art legal series The Good Wife were taken. Example:

- eng. I think that it would be fairer if we decide this matter on the law, not on the passions of a jury. - ukr. Я думаю, що буде чесно вирішувати питання засобами закону, а не пристрастями людськими.;

- eng. - That might be true, but I'mnot gonna try and, uh, rile up those passions. - ukr. Можливо, ие так, але я не збираюся закликати до иих пристрастей.

After analyzing this passage, we can conclude that using the transformations of semantic developmentand omission, the translation of the phrase the passions of a jury which includes the legal terminology unit jury (jury trial), as a metaphor for nристрасті людські of Ukrainian linguistic culture. Despite the violation of the norms of translation equivalence, it was possible to adhere to the pragmatic and conventional norms of translation quality [10, p. 75-79].

The lexical units from the following example belong to the same group: eng. - Objection, Your Honor. - ukr. Протесmyю, Bama честь.; eng. - On what grounds? - ukr. Причина? In this case, there was a translation at the level of description of the situation, abandoning the terminological legal phrase on what grounds (на яких підставах), and transfer it as a commonly used unit of reason, which may become terminological in the legal context. This episode includes other cases of using the transformation of semantic development in the transfer of legal terms, which from the beginning had a terminological nature and partially lose it in translation, for example: eng. I hope we can make a deal today. Ijust hate this courtroom fighting. - ukr. Я сподіваюся, щуо ми нарешті домовимося. Мене вже нудить від зала суду.

In the following passage we can see the use of the transformation of anatomical translation in the transfer of phrases from common vocabulary $I$ will allow in the legal context and the formation of a terminological unit of rejection, which is characteristic of the court register of law: eng. Objection. Your Honor, this was excluded from the previous trial for relevance. - ukr. Протестую, Вама честь. Ці матеріали були визнані такими, щзо не відносяться до справи.; eng. - I will allow. - ukr. Biдхиляю. In another passage, the use of anatomical translation to convey the same term was avoided: eng. - Overruled. - ukr. Відхиляю.

The contextual emotionality of the English verb to slap (плескати, вдарити) decreased and this lexical unit was transferred to the neutral Ukrainian equivalent to appoint, which is usually used in the terminological units of legal terminology (for example, призначити залог), for example: eng. After you pled "not guilty,” Clayton, what happened then? - укр. Що біло після того, як ви заявили про невинність?; англ. The judge slapped me with a six-figure bail. - укр. Суддя призначив залог з шістьма нулями.

The term, in turn, can retain terminology in translation. In this case, the translation is reproduced both in context and in vocabulary. When translating in context, the translator may, among other things, be guided by the pragmatic norm of translation within the framework of off-screen translation. In this case, translation techniques (eg, transformation generalization) are aimed at compressing the message of the original language. Vocabulary translation involves the use of additional mechanisms that change the emotional expression. This tendency can be manifested in sentences that change the modality of translation. The change of modality can be dictated by the disjointed nature of the system of modal verbs [11, p. 94-102].

The results of the study showed that the most common method of translation is the use of the full equivalent of the term. This method of translation is best suited to convey the professional atmosphere and indirect characteristics of the characters. Problems of translation of legal terminology are of additional interest in various aspects and it would be useful to study other aspects of the functioning of English legal terminology. These issues, in terms of linguistics, cognitive linguistics, discourse and stylistics, may be the subject of further research.

\section{References:}

1. Назарєва Є. В. Характерні риси кінотексту як форми художньої реальності. Філологічні науки. Питання теорії і практики. Рецензований науковий журнал. Вип. № 2 (56): в 2-х ч. Ч. 2. Т. : видавництво Грамота, 2016. С. 95-98.

2. Герд А.С. Спеціальний текст як предмет прикладного мово-знавства. Прикладне мовознавство. СПб., 2006. С. 68-90.

3. Максименко Є.С., Національно-культурна специфіка номінації універсальних правових аспектів, що створює наукову картину світу, в англійській та американській юридичній термінології. Мови професійної комунікації: Матеріали міжнародної наукової конференції / відп. ред. Е.І. Голованова. Ч. 2006. С. 313-316.

4. Tiersma P.M. Legal Language Chicago and London. Chicago : The University of Chicago Press, 2009. 314 p.

5. Лутцева М. В. Англійська юридична термінологія та способи ії перекладу на українську мову. Вісник лінгвістичний. Серія: Лінгвістика та міжкультурна комунікація. 2007. № 2-1. С. 110-113.

6. Глинська Н.Р. Юридична термінологія в різних функціональних стилях англійської мови : дис. канд. філол. наук. М. 2002. 209 с.

7. Ron Binkowski, Corinne Brinkerhoff (Producers), 2009-2016 years. The Good Wife. United States of America, British Columbia.

8. Bhatia V. K. Analyzing Genre: Language Use In Professional Settings London and New York: Longman, 2009. 246 p.

9. Нелюбин Л. Л. Тлумачний перекладацький словник. Москва : Флінта, Наука, 2009. 320 с.

10. Хижняк С.П. Формування та розвиток термінологічності в мовній системі (на матеріалі юридичної термінології): автореф. дис. д-ра. філол. наук. С., 2008.38 с.

11. Слишкін Г.Г. Єфремова М.А. Кінотекст (досвід лінгвокультурного аналізу): монографія. Москва : Видавництво «Водолій Publishers», 2008. СПб., 2007. 164 c.

12. Agatha Christie The Murder of Roger Ackroyd, 2006, Pairot Facsimile Edition (Facsimile of 1926 UK First Edition), HarperCollins, September 4, 2006, Hardback ISBN 0-00-723437-6.

13. Agatha Christie The Mysterious Affair at Styles, 2007, Facsimile of 1921 UK first edition (Harper Collins), November 5, 2007, Hardcover, 296 pp ISBN 0-00-726513-1.

Шуменко О. А., Кашенко П. В., Савченко С. О. Англомовна юридична термінологія в контексті художнього перекладу

Анотація. Стаття присвячена англомовній юридичній термінології в контексті художнього перекладу. Вибір даної теми зумовлений тим, що основні проблеми під час перекладу художніх творів та кінофільмів, у яких присутній 
юридичний дискурс, можуть бути пов'язані не стільки 3 обмеженими знаннями перекладача в правничій термінології, скільки зі збереженням задуму автора та стилістичних функцій терміна. Завдяки концептам, які опрацьовувалися у цій статті, було виявлено особливості способів перекладу та відтворення проблем, що виникали в ході перекладу юридичної термінології. Стаття зосереджується на термінології, що вживається у правничій галузі, та на прикладах їх вживання у художньому тексті та кінофільмі. Перед тим, як перейти до формування основних результатів даної роботи, слід було правильно окреслити межі поняття «юридичний термін», тому було сформовано визначення, у якому було зазначено, що юридичний термін - це мовне означення державно-правових понять, за допомогою яких виражається і закріплюється зміст нормативно правових розпоряджень держиви.

Дана робота розглядає особливості перекладу юридичної термінології, оскільки головну роль під час перекладу юридичних текстів грає не тільки володіння знаннями правових норм, юридичної термінології, судово-процесуальних систем, але й особові якості перекладача, оскільки переклад будь-якого тексту допускає взаємодію двох суверенних національних мов, а також міжкультурних аспектів.

Насамперед розглядається специфіка навчального технічного та художнього перекладу, який передбачає спеціальну літературу в правничій галузі. Здійснений аналіз джерел та типів юридичних термінів англійської мови. Окреслено основні перекладацькі труднощі, які можуть виникати під час роботи з англомовним художнім текстом, що включає в себе юридичну термінологію. Проаналізовано лексичні та граматичні трансформації, що використовуються під час перекладу юридичного тексту.

Ключові слова: юридична термінологія, юридичний дискурс, художній дискурс, правнича система, способи перекладу. 